\title{
Establishing Vegetation on Migrating Inland Sand Dunes in Texas
}

\author{
Timothy E. Fulbright, ${ }^{1}$ J. Alfonso Ortega-Santos, ${ }^{2}$ \\ Alejandro Lozano-Cavazos, ${ }^{3}$ and Luis Enrique Ramirez-Yanez ${ }^{3}$ \\ Authors are ${ }^{1}$ Regents Professor and Meadows Professor in Semiarid Land Ecology; ${ }^{2}$ Assistant Professor, and \\ ${ }^{3}$ Graduate Research Assistants, Caesar Kleberg Wildlife Research Institute, Department of Animal and Wildlife Sciences, \\ Texas AひM University-Kingsville, Kingsville, TX 78363.
}

\begin{abstract}
Migration of sand dunes damages range improvements in the Texas Coastal Sand Plain. We determined effects of mulching with native prairie hay and an open weave geotextile fabric, seeding, fertilization, and transplanting on plant species canopy cover on inland sand dunes. We compared applying native hay vs. a synthetic geotextile material to inhibit wind erosion, seeding 'Alamo' switchgrass (Panicum virgatum L.), 'Mason' sandhill lovegrass (Eragrostis trichodes [Nutt.] Wood), and partridge pea (Chamaecrista fasciculata [Michx.] Greene) vs. no seeding, and fertilization with $468 \mathrm{~kg} \cdot \mathrm{ha}^{-1}$ of 45:45:90 (N:P:K) vs. no fertilization. The same treatments were compared in a second experiment except that switchgrass, sandhill lovegrass, vetiver (Vetiveria zizanoides [L.] Nash ex Small), and giant reed (Arundo donax L.) were transplanted rather than seeded. Treatments were applied during March and April 1994 and canopy cover of vegetation in each experimental unit was estimated in October 1994, 1995, and 2004. Livestock were excluded from the study sites. The geotextile fabric degraded within 4 months and was replaced with coastal Bermuda (Cynodon dactylon [L.] Pers.) hay. Fertilization plus native hay mulch resulted in greater $(P<0.05)$ canopy cover of purple sandgrass (Triplasis purpurea [Walt.] Chapm.), sandbur (Cenchrus incertus M. A. Curtis and C. echinatus L.), and snakecotton (Froelichia spp.) than other treatments in 1994. In 1994 and 1995, canopy cover of switchgrass and sandhill lovegrass was greater $(P<0.05)$ with a combination of geotextile fabric and commercial hay, seeding, and fertilization than in other treatments. Vegetation composition and canopy cover were similar $(P>0.05)$ across treatments in 2004 in both experiments. Fertilization, seeding, and transplanting appear unnecessary to establish vegetation on dunes protected from livestock grazing when mulch is applied to inhibit sand movement.
\end{abstract}

\section{Resumen}

El movimiento de dunas de arena perjudica las prácticas de mejoramiento de agostaderos en la región del Texas Coastal Sand Plain. El objetivo del presente estudio fue determinar los efectos del acolchado con heno de pastos nativos y una malla textil además de la fertilización, trasplante, y siembra directa sobre la cobertura aérea de la vegetación en las dunas. Se comparó la malla textil contra el uso de heno para evitar la erosión eólica, la siembra directa de 'Alamo' switchgrass (Panicum virgatum L.), 'Mason' sandhill lovegrass (Eragrostis trichodes [Nutt.] Wood), y partridge pea (Chamaecrista fasciculata [Michx.] Greene) contra no siembra, y la fertilización con $468 \mathrm{~kg} \cdot \mathrm{ha}^{-1}$ de 45:45:90 (N:P:K) contra no fertilización. Los mismos tratamientos se compararon en un segundo experimento con la excepción de que se trasplantaron switchgrass, sandhill lovegrass, vetiver (Vetiveria zizanoides [L.] Nash ex Small), y carrizo (Arundo donax L.) en lugar de sembrados directamente. Los tratamientos se aplicaron en Marzo y Abril de 1994 y la cobertura aérea de la vegetación en cada unidad experimental se estimó en Octubre de 1994, 1995, y 2004. Los sitios se mantuvieron excluidos de pastoreo. La malla textil se degradó en los primeros 4 meses del estudio y se reemplazo con heno de zacate Bermuda (Cynodon dactylon [L.] Pers.). La fertilización en combinación con el acolchado con heno de pastos nativos presentó la cobertura aérea mas alta $(P<0.05)$ de purple sandgrass (Triplasis purpurea [Walt.] Chapm.), sandbur (Cenchrus incertus M. A. Curtis y C. echinatus L.), y snakecotton (Froelichia spp.) comparado con el resto de los tratamientos en 1994. En 1994 y 1995 la cobertura aérea de switchgrass y sandhill lovegrass fue mas alta $(P<0.05)$ en la combinación de malla textil, siembra directa, y fertilización comparado con el resto de los tratamientos. La composición de la vegetación y la cobertura aérea fueron similares $(P>0.05)$ entre tratamientos en 2004 en ambos experimentos. La fertilización, siembra directa, y el trasplante son aparentemente innecesarios para establecer vegetación en las dunas protegidas del pastoreo de ganado cuando se utiliza el acolchado para inhibir el movimiento de las dunas.

Key Words: Eragrostis trichodes, fertilization, mulch, Panicum virgatum, Vetiveria zizanoides, wind erosion

Research was funded by the John G. and Marie Stella Kenedy Memorial Foundation and the Caesar Kleberg Wildlife Research Institute. This is Caesar Kleberg Wildlife Research Institute manuscript 06-108.

Mention of a proprietary product does not constitute a guarantee or warranty of the product by Texas A\&M University-Kingsville and does not imply its approval to the exclusion of other products that also may be suitable.

Correspondence: Timothy E. Fulbright, Caesar Kleberg Wildlife Research Institute, 700 University Blvd, MSC 218, Texas A\&M University-Kingsville, Kingsville, TX 78363. Email: timothy.fulbrigh@@tamuk.edu

Manuscript received 6 March 2006; manuscript accepted 7 June 2006.

\section{INTRODUCTION}

Migrating sand dunes cover about $5 \%$ of the land surface of the 1-million-ha Coastal Sand Plain in southern Texas (Fulbright et al. 1990). These inland sand dunes are a picturesque component of the region and add to landscape and biotic diversity (Fulbright and Bryant 2002). Migration of individual dunes, however, often damages or covers range developments and facilities including roads, fences, water wells, livestock 
working pens, and hunting camps. Stabilization of dunes that threaten valuable ranch infrastructure with vegetation reduces or prevents economic loss, increases the amount of forage available to livestock, and improves habitat for economically important wildlife species such as white-tailed deer (Odocoileus virginianus Raff.) and northern bobwhite quail (Colinus virginianus L.).

Establishing and maintaining a cover of vegetation is the most effective method of controlling wind eroded sand dunes (Armbrust 1977). Plants can be established on dunes either by direct seeding or by transplanting. Direct seeding is less expensive than transplanting (Whisenant 1999); however, soil moisture must be sufficient for an adequate period of time for seeds to germinate and for seedlings to establish. Moisture availability can be severely limited in the sandy soil of dunes, particularly in the hot, drought-prone environment of southern Texas. Transplanting seedlings is advantageous in harsh environments such as sand dunes because the germination phase is bypassed and seedlings have established a root system. For these reasons, transplanting is commonly considered to be far more successful than seeding to establish vegetation on sand dunes (Salmon et al. 1982).

Mulching material to reduce movement of sand is essential in establishing vegetation on dunes (Armbrust 1977). Synthetic mulching material is widely available for use in revegetation. Mulching with native prairie hay can be advantageous compared to synthetic material because native plant seeds are present in the hay (Whisenant 1999). Although mulching alone did not increase vegetation establishment in restoration plantings in Colorado, there appeared to be a synergistic effect when mulch was combined with fertilizer (Pascke et al. 2000). Sand dunes are inherently low in nutrients and several researchers have reported that adding fertilizer, particularly nitrogen, stimulates vegetation growth (Blake et al. 1973).

Our overall objective was to determine the most effective combination of mulching, seeding, fertilization, and plant transplanting to establish vegetation on migrating inland sand dunes in the Texas Coastal Sand Plain. The specific objective was to determine the effects of mulching with native prairie hay and a synthetic fabric, seeding, fertilization, and transplanting on plant species composition and percent canopy cover. We hypothesized that 1) mulching with native prairie hay results in greater vegetation canopy cover on migrating dunes than mulching with synthetic fabric, 2) seeding or transplanting results in greater canopy cover of vegetation than unplanted controls, and 3) fertilization results in greater vegetation canopy cover than unfertilized plots on migrating dunes.

\section{METHODS}

\section{Study Area}

Research was conducted on a private ranch in Kenedy County, Texas. The study site was in a 10000 -ha pasture about $35 \mathrm{~km}$ south of Sarita, Texas (lat $27^{\circ} 00^{\prime} 40^{\prime \prime} \mathrm{N}$, long $\left.97^{\circ} 41^{\prime} 30^{\prime \prime} \mathrm{W}\right)$. Soils of the Coastal Sand Plain consist of wind-worked Quaternary eolian sand; dune ridges are typically Entisols whereas flats and drainages are generally Alfisols (Diamond and Fulbright 1990). The climate is subhumid, subtropical with extreme variations in annual precipitation caused by periodic droughts and hurri- canes (Fulbright et al. 1990). Average (1936-2004) annual rainfall is $747 \mathrm{~mm}$ in the study area based on ranch records, with peaks occurring in May-June and September-October. Average rainfall during the study (1994-2004) was $788 \mathrm{~mm}$ and ranged from $430 \mathrm{~mm}$ in 1996 to $1070 \mathrm{~mm}$ in 1997 . The prevailing winds are from the southeast, resulting in dune migration from southeast to northwest.

Vegetation of the Coastal Sand Plain is characterized by tall and mid grass prairie interspersed with mottes of live oak (Quercus virginiana Mill.) and honey mesquite (Prosopis glandulosa var. glandulosa Torr.) (Diamond and Fulbright 1990; Fulbright et al. 1990). The dominant grass species is seacoast bluestem (Schizachyrium scoparium var. littoralis Nash.). Dominant forb species include partridge pea, camphorweed (Heterotheca subaxillaris [Lam.] Britt. \& Rusby), and round copperleaf (Acalypha radians Torr.).

Two spatially separated dunes about $1 \mathrm{~km}$ apart and 0.4 and 0.6 ha in size were selected for the study and were surrounded with a 1.2-m-tall woven wire fence to exclude livestock. The density of the woven-wire fence was $<5 \%$ and it was sufficiently distant from the dunes to not affect wind velocity (Brandle et al. 2004). Twelve plots, each measuring $12 \times 12 \mathrm{~m}$, were established on each dune. Half of the plots on each dune were used for experiment 1 and half were used for experiment 2 .

\section{Experiment 1}

The objective of Experiment 1 was to determine the effects of mulching with native hay vs. synthetic material, artificial seeding, and fertilization on establishment of vegetation. A split-plot experimental design was used in the experiment, with mulching treatment as the whole plots and artificial seeding with fertilization, artificial seeding with no fertilizer, no seeding with fertilization, and no seeding or fertilization as subplots. Whole plots (mulch treatment/replication combination) measured $12 \times 12 \mathrm{~m}$ and were separated by a 4-m-wide buffer. Subplots were $6 \times 6 \mathrm{~m}$ and were spatially separated by $2-\mathrm{m}-$ wide buffers. A $0.9-\mathrm{m}$ tall poultry netting fence was erected in the center of each buffer to reduce the possibility of native hay particles contaminating the geotextile fabric mulching treatments. The fence was not intended as a windbreak and probably had a negligible effect on wind velocity because density of the structure was $<10 \%$ (Brandle et al. 2004). The experiment was replicated 6 times, with 3 replications on each of the 2 spatially separated dunes.

Mulching materials, artificial seeding, and fertilizer were applied during March and April 1994. Native hay was cut and baled in October 1993 from a site adjacent to the dunes and 5 metric tons $(\mathrm{mt}) \cdot \mathrm{ha}^{-1}$ were applied to experimental units receiving the native hay treatment. The synthetic mulch material used in the experiment was a commercially available, biodegradable, openweave geotextile fabric used for erosion control. The aperture size of the fabric was 0.25 to $0.30 \mathrm{~cm}$ and the mullen burst strength of the fabric was $5.2 \mathrm{~kg}$-force $\cdot \mathrm{cm}^{-2}$.

The artificial seeding treatment was a mixture of 4.48 $\mathrm{kg} \cdot \mathrm{ha}^{-1}$ pure live seed (PLS) 'Alamo' switchgrass, 1.68 $\mathrm{kg} \cdot \mathrm{ha}^{-1}$ PLS 'Mason' sandhill lovegrass, and $2.24 \mathrm{~kg} \cdot \mathrm{ha}^{-1}$ partridge pea. These species were chosen because of their adaptation to sandy soils and commercial availability. Seeds were broadcast with a handheld spreader. Seeds were coated 
with clay by a commercial seed company to improve evenness of seed distribution during broadcasting.

A composite soil sample taken from 83 to 86 systematically collected subsamples on each dune was analyzed to determine soil texture, $\mathrm{pH}$, nitrogen, phosphorus, potassium, micronutrients, boron, lime, and organic matter by the Texas A\&M University System Soil Testing Laboratory. Soil samples were collected from 0 to $15 \mathrm{~cm}$ and 15 to $30 \mathrm{~cm}$. Based on soil analyses, the Texas A\&M University Soil Testing laboratory recommended a fertilizer application rate of $468 \mathrm{~kg} \cdot \mathrm{ha}^{-1}$ of 45:45:90 (ratio of nitrogen, phosphorus, and potassium) with $1 \%$ zinc, $1 \%$ chelated iron, and $0.25 \%$ boron to provide adequate nutrients for plant growth. Fertilizer was broadcast with a handheld spreader.

Seeds and fertilizer were applied to the native hay treatment after an initial application of $2.5 \mathrm{mt} \cdot \mathrm{ha}^{-1}$ of hay. Seeds, fertilizer, and hay were incorporated to a depth of 5 to 10 $\mathrm{mm}$ in the soil using a light disk harrow pulled by an all- terrain vehicle. The remainder of the hay, $2.5 \mathrm{mt} \cdot \mathrm{ha}^{-1}$, was applied following the disking treatment. In the geotextile fabric treatment, seeds and fertilizer were first broadcast over the sand and incorporated to a depth of 5 to $10 \mathrm{~mm}$ in the sand using a 1.8-m-wide wooden drag with nails protruding out about $15 \mathrm{~mm}$ and spaced 10 to $15 \mathrm{~cm}$ apart. A $3 \mathrm{~m}$ section of chain was attached to each end of the drag to form a half circle when pulled behind the drag to ensure that the seeds were covered by sand. Following application of the drag, the synthetic fabric was rolled over the plot and anchored in the sand using 15 -cm-long metal staples. Percent canopy cover of plant species, bare ground, and litter were visually estimated in October 1994, 1995, and 2004 using 21, $20 \times 50 \mathrm{~cm}$ quadrats/ experimental unit (Bonham 1989:128-129). Seven quadrats were placed $0.45 \mathrm{~m}$ apart along a randomly selected side of 3 , $4 \mathrm{~m}$ transects within each $6 \times 6 \mathrm{~m}$ subplot. Data were analyzed using analysis of variance (ANOVA) for a split-plot design with mulching treatment as the main plot effect and a factorial arrangement of seeding and fertilizer treatments as the subplots (SAS Institute 1989). The Kenward-Rogers method was used for the assumed unstructured variance components for the covariance structure in the statistical analyses (Littell et al. 1996). The least squares means procedure with the SIMULATE adjustment was used to compare means $(P>0.05)$. Separate analyses were conducted for each mulch treatment when the mulch $\times$ fertilizer $\times$ seeding treatment interaction was significant with fertilizer treatment as the main plot effect and seeding as the subplot. Statistical analyses were conducted for bare ground, litter, cover of standing dead plant material, and canopy cover of plant species with $>2 \%$ canopy cover averaged across treatments.

\section{Experiment 2}

The objective of Experiment 2 was to determine effects of mulching with native hay vs. geotextile fabric, fertilization, and plant transplanting on establishment of vegetation. A splitsplit-plot experimental design was used in the experiment, with mulching treatment as the whole plots, fertilization treatment as the subplot, and plant species (4) as the sub-subplot. Each subplot was $12 \times 12 \mathrm{~m}$ and was spatially separated from other subplots by 2 -m-wide buffers; sub-sub plots measured $3 \times 6 \mathrm{~m}$.
A 0.9-m-tall poultry netting fence was erected in the center of each buffer as in Experiment 1. The experiment was replicated 6 times, with 3 replications on each dune. Treatments were applied during March and April 1994.

Transplants included seedlings of 'Alamo' switchgrass and 'Mason' sandhill lovegrass, slips of vetiver, and phytomers of giant reed. 'Alamo' switchgrass and 'Mason' sandhill lovegrass seedlings were about 1 month old when planted and were grown in a commercial greenhouse. Vetiver transplants were obtained from the U.S. Department of Agriculture Natural Resources Conservation Service Kika de la Garza Plant Materials Center at Kingsville, Texas. Vetiver was chosen because of its popularity for use in erosion control (National Research Council 1993). Phytomers of giant reed were harvested by hand and planted immediately after harvesting. Giant reed was planted at the recommendation of local ranchers who anecdotally observed successful dune stabilization from placing freshly-cut giant reed stems on migrating dunes. Transplants, slips, and phytomers were planted by hand and spaced $60 \mathrm{~cm}$ apart in the native hay and geotextile fabric treatments (Salmon et al. 1982).

Fertilizer was applied to the native hay and geotextile fabric treatments at a rate of $468 \mathrm{~kg} \cdot \mathrm{ha}^{-1}$ of $45: 45: 90$ with $1 \%$ zinc, $1 \%$ chelated iron, and $0.25 \%$ boron. Native hay in experiment 2 was applied at a rate of $7.5 \mathrm{mt} \cdot \mathrm{ha}^{-1}$ with $2.5 \mathrm{mt} \cdot \mathrm{ha}^{-1}$ applied initially. Fertilizer was applied over the initial layer of hay. The hay was then anchored with a disk harrow to bind it to the sand. Following this, another $2.5 \mathrm{mt} \cdot \mathrm{ha}^{-1}$ of hay was applied and incorporated into the sand with the harrow, after which the final $2.5 \mathrm{mt} \cdot \mathrm{ha}^{-1}$ of hay was placed over the plot. In the geotextile fabric treatment, fertilizer was applied to the sand and the geotextile fabric was then rolled onto the dune and anchored with metal staples.

Percent canopy cover of plant species, bare ground, and litter were visually estimated in October 1994, 1995, and 2004 using 10, $20 \times 50 \mathrm{~cm}$ quadrats/experimental unit. Five quadrats were placed $0.8 \mathrm{~m}$ apart along a randomly selected side of 2, $4 \mathrm{~m}$ transects within each $3 \times 6 \mathrm{~m}$ subplot. Canopy cover data were analyzed using analysis of variance for a splitsplit-plot design with mulching treatment as the main plot effect, fertilizer treatment as the sub-plot, and transplant species the sub-sub-plots (SAS Institute 1989). Means comparisons were conducted as described for Experiment 1. Statistical analyses were conducted for bare ground, litter, cover of standing dead plant material, and canopy cover of plant species with $>2 \%$ canopy cover averaged across treatments.

\section{RESULTS}

Soils in the upper $30 \mathrm{~cm}$ of the dunes were $\geq 91 \%$ sand with $\leq 0.1 \%$ organic matter, $1 \mu \mathrm{g} \cdot \mathrm{g}^{-1} \mathrm{~N}, \leq 2 \mu \mathrm{g} \cdot \mathrm{g}^{-1} \mathrm{P}, \leq 40$ $\mu \mathrm{g} \cdot \mathrm{g}^{-1} \mathrm{~K}$, and had $\mathrm{pH}$ ranging from 7.1 to 8.3 . Strong winds and photodegradation resulted in tearing of the geotextile fabric into fragments that blew from the dunes, exposing bare soil. The geotextile fabric was replaced with coastal Bermuda (Cynodon dactylon [L.] Pers.) hay $\left(7.5 \mathrm{mt} \cdot \mathrm{ha}^{-1}\right.$ ) in July 1994 to minimize wind erosion and prevent deposition of sand on other treatments. The treatment of applying the geotextile fabric followed by application of coastal Bermuda hay 4 
Table 1. Dependent variables with $>2 \%$ canopy cover during October 1994, 1995, and 2004 having significant $\left({ }^{*} 0.05-0.01,{ }^{\star *} 0.01-0.001\right.$, and $\left.{ }^{* * *}>0.001\right) P$ values for main effects or interactions in analyses of variance. Independent variables in analyses were application of native hay vs. geotextile fabric followed by commercial hay (M), fertilizer vs. no fertilizer (F), and seeding partridge pea, sandhill lovegrass, and switchgrass vs. no seeding (S) during March and April 1994 to establish vegetation on sand dunes, Kenedy County, Texas. Numerator and denominator degrees of freedom for calculation of $F$ values were 1 and 5 for mulch and 1 and 30 for other main effects and interactions.

\begin{tabular}{|c|c|c|c|c|c|c|c|}
\hline \multirow{2}{*}{$\begin{array}{l}\text { Year and } \\
\text { variable }\end{array}$} & \multirow{2}{*}{$\begin{array}{c}\text { Mulch } \\
\text { (M) }\end{array}$} & \multirow{2}{*}{$\begin{array}{c}\text { Fertilizer } \\
\text { (F) }\end{array}$} & \multicolumn{3}{|c|}{ Seed } & \multicolumn{2}{|r|}{$M \times S$} \\
\hline & & & $M \times F$ & $(\mathrm{~S})$ & $M \times S$ & $F \times S$ & $\times F$ \\
\hline \multicolumn{8}{|l|}{1994} \\
\hline Bare ground & & $\star \star$ & & & & & \\
\hline Litter & $\star \star \star$ & $\star \star \star$ & & & & & \\
\hline \multicolumn{8}{|l|}{ Seeded species } \\
\hline Partridge pea & $\star \star \star$ & $\star \star *$ & $\star \star \star$ & & & & \\
\hline Sandhill lovegrass & $\star *$ & $\star * *$ & $* *$ & $* \star *$ & $\star * *$ & $\star *$ & * \\
\hline Switchgrass & & * & & * & & * & \\
\hline \multicolumn{8}{|l|}{ Nonseeded species } \\
\hline Flatsedge & & & * & & & & \\
\hline Purple sandgrass & $\star \star$ & $\star \star *$ & $* * *$ & & & & \\
\hline Sandbur & $\star *$ & $\star \star \star$ & $\star * *$ & & & & \\
\hline \multicolumn{8}{|l|}{1995} \\
\hline Bare ground & * & $\star *$ & & & & & \\
\hline Litter & $\star \star$ & $\star \star *$ & $\star \star \star$ & & & & \\
\hline Standing dead & $\star *$ & $\star \star \star$ & $\star \star \star$ & & & & \\
\hline \multicolumn{8}{|l|}{ Seeded species } \\
\hline Sandhill lovegrass & $\star *$ & * & * & $\star *$ & * & & \\
\hline Switchgrass & * & $\star \star \star$ & * & $\star \star \star$ & * & $\star \star \star$ & * \\
\hline \multicolumn{8}{|l|}{ Nonseeded species } \\
\hline $\begin{array}{l}\text { American snoutbean } \\
\text { (Rhynchosia } \\
\text { americana } \\
\text { [Mill.] C. Metz.) }\end{array}$ & & * & & & & & \\
\hline Purple sandgrass & $\star *$ & $\star * *$ & & * & $\star * *$ & & \\
\hline Sandbur & $\star *$ & $\star *$ & $* * *$ & & & & \\
\hline Threeawns & & & & & & * & * \\
\hline \multicolumn{8}{|l|}{2004} \\
\hline Standing dead & & & & * & & & \\
\hline Brownseed paspalum & & & & & & * & * \\
\hline
\end{tabular}

months later will be referred to as the commercial hay treatment throughout the paper.

\section{Experiment 1}

Canopy cover of partridge pea (averaged across seeding treatments in 1994) was 19 times greater in plots where native hay was applied with no fertilizer than in fertilized plots; only trace amounts of partridge pea were present in plots with commercial hay (Table 1). In contrast to 1994, partridge pea was virtually absent from treatment plots in 1995.
Canopy cover of sandhill lovegrass and switchgrass was greater in fertilized commercial hay treatments in 1994 (23 $\pm 7 \%$, mean \pm SE, $n=12$; and $12 \pm 4 \%$, respectively) and $1995(14 \pm 4 \%$ and $11 \pm 4 \%$, respectively), than in other treatments $(\leq 5 \pm 3 \%)$ (Table 1$)$. Plant species that were not seeded but composed $>2 \%$ canopy cover across treatments include snakecotton, sandbur, and purple sandgrass (Tables 1 and 2). Canopy cover of these species was greater in fertilized native hay plots than in other treatments in 1994. Only a trace amount of snakecotton was present in the native hay mulch treatment in 1995. Sandbur canopy cover was also greater in fertilized native hay plots in 1995. In contrast to 1994, averaged across mulch and seeding treatments, purple sandgrass canopy cover was greater with no fertilizer $(48 \pm 4 \%$, $n=24)$ than in fertilized treatments $(26 \pm 4 \%)$ in 1995. In 1995 , purple sandgrass canopy cover was greater (LS means, $P<0.05)$ with commercial hay and no seeding $(60 \pm 5 \%$, $n=12)$ than in treatments with native hay mulch and no seeding $(23 \pm 5 \%)$, native hay mulch and seeding ( $30 \pm 6 \%)$, or commercial hay and seeding $(34 \pm 6 \%)$, when averaged across fertilizer treatments.

Separate analyses were conducted for each mulching treatment for threeawn (Aristida spp.) canopy cover in 1995 (Tables 1 and 2). The fertilizer and seed main effects and fertilizer $\times$ seed interaction were not significant in the native hay mulch treatment $(P=0.303, P=0.940$, and $P=0.991$; respectively) or commercial hay $(P=0.689, P=0.759$, and $P=0.053$; respectively).

Rainfall was above average during 2002-2004; therefore canopy cover and plant species composition on the dunes were not restricted by low rainfall. Plant species seeded in 1994 did not persist 1 decade after planting; sandhill lovegrass was not encountered during sampling, and switchgrass and partridge pea were present only in trace amounts.

Hoary milkpea (Galactia canescens Benth.) and camphorweed were the dominant plant species in 2004, with canopy cover of each species similar among treatments (Table 2). Canopy cover of other plant species was also similar among treatments in 2004, except that canopy cover of brownseed paspalum (Paspalum plicatulum Michx.) was slightly greater on plots mulched with native hay.

\section{Experiment 2}

Canopy cover of sandhill lovegrass, switchgrass, and vetiver was greater in fertilized commercial hay than in other treatments in 1994 and 1995 (Table 3). Canopy cover of transplanted grasses was negligible $(\leq 5 \%)$ one decade after planting. Interestingly, a trace amount of giant reed was present in 2004 even though no sprouting was evident during the first 2 years of the study.

Plant species that were not transplanted with canopy cover $>2 \%$ averaged across treatments in 1994 included partridge pea, snakecotton, sandbur, and purple sandgrass. As in Experiment 1 , canopy cover of partridge pea was greater in plots where native hay was applied with no fertilizer than in fertilized plots, or plots with commercial hay in 1994 (Tables 4 and 5). Sandbur and purple sandgrass canopy cover were greater in fertilized native hay plots than in other treatments. In 1995, averaged across mulch and transplanting treatments, purple 
Table 2. Means and standard errors (SE) $(n=12)$ averaged across seeding treatments for percent bare ground, litter, standing dead plant material, and canopy cover of selected plant species during October 1994, 1995, and 2004. Treatments were applying native hay vs. geotextile fabric followed by commercial hay, fertilizer vs. no fertilizer, and seeding partridge pea, sandhill lovegrass, and switchgrass vs. no seeding during March and April 1994 to establish vegetation on sand dunes, Kenedy County, Texas.

\begin{tabular}{|c|c|c|c|c|c|c|c|c|}
\hline \multirow[b]{3}{*}{ Category or plant name } & \multicolumn{4}{|c|}{ Native hay } & \multicolumn{4}{|c|}{ Geotextile fabric } \\
\hline & \multicolumn{2}{|c|}{ Control } & \multicolumn{2}{|c|}{ Fertilized } & \multicolumn{2}{|c|}{ Control } & \multicolumn{2}{|c|}{ Fertilized } \\
\hline & Mean & SE & Mean & SE & Mean & SE & Mean & SE \\
\hline \multicolumn{9}{|l|}{1994} \\
\hline Bare ground & 9 & 3 & $T^{1}$ & & 11 & 5 & 3 & 1 \\
\hline Litter & 21 & 5 & $\mathrm{~T}$ & & 65 & 7 & 33 & 8 \\
\hline Standing dead & 4 & 2 & 9 & 7 & 3 & 2 & 1 & 1 \\
\hline Amaranthus sp. & 0 & & 0 & & 4 & 4 & 7 & 4 \\
\hline Snakecotton & $5 b$ & 1 & $29 a$ & 8 & $0 b$ & & ob & \\
\hline Flatsedge & 3a & 3 & Ta & & Ta & & $10 \mathrm{a}$ & 6 \\
\hline Purple sandgrass & $29 b$ & 4 & $79 a$ & 8 & $8 b$ & 2 & $16 b$ & 8 \\
\hline Sandbur & $\mathrm{Tb}$ & & $20 \mathrm{a}$ & 4 & $0 b$ & & ob & \\
\hline Threeawns & 2 & 1 & 5 & 3 & 2 & 1 & 3 & 1 \\
\hline Other species & 1 & 1 & 4 & 2 & 2 & 2 & 2 & 1 \\
\hline \multicolumn{9}{|l|}{1995} \\
\hline Bare ground & 8 & 2 & $\mathrm{~T}$ & & 9 & 2 & 6 & 1 \\
\hline Litter & $8 b$ & 2 & $54 a$ & 5 & $5 b$ & 1 & $14 b$ & 2 \\
\hline Standing dead & $34 a$ & 4 & $5 b$ & 2 & $7 b$ & 3 & $4 b$ & 1 \\
\hline American snoutbean & 4 & 2 & T & & 4 & 1 & 1 & 1 \\
\hline Purple sandgrass & 39 & 4 & 14 & 3 & 56 & 6 & 38 & 7 \\
\hline Sandbur & $4 b$ & 1 & $18 \mathrm{a}$ & 4 & $0 b$ & & $\mathrm{~Tb}$ & \\
\hline Sunflower (Helianthus spp.) & 4 & 2 & 0 & & 11 & 5 & 5 & 2 \\
\hline Threeawns & 7 & 2 & 4 & 2 & 13 & 5 & 14 & 4 \\
\hline Other species & 11 & 5 & 6 & 4 & 12 & 4 & 6 & 2 \\
\hline \multicolumn{9}{|l|}{2004} \\
\hline Bare ground & 14 & 2 & 16 & 4 & 23 & 3 & 21 & 4 \\
\hline Litter & 11 & 2 & 13 & 2 & 12 & 3 & 15 & 2 \\
\hline Standing dead & 8 & 1 & 6 & 1 & 6 & 1 & 6 & 1 \\
\hline Brownseed paspalum & 6 & 2 & 7 & 2 & $\mathrm{~T}$ & & 1 & 1 \\
\hline Camphorweed & 34 & 3 & 30 & 5 & 27 & 3 & 28 & 3 \\
\hline Hoary milkpea & 26 & 2 & 30 & 4 & 27 & 2 & 31 & 3 \\
\hline Sandbur & 1 & 1 & 2 & 1 & 3 & 2 & 3 & 1 \\
\hline Threeawns & 2 & 1 & $\mathrm{~T}$ & & 5 & 2 & 6 & 2 \\
\hline Other species & 11 & 5 & 6 & 4 & 6 & 2 & 3 & 1 \\
\hline
\end{tabular}

${ }^{1} \mathrm{~T}=$ trace amount.

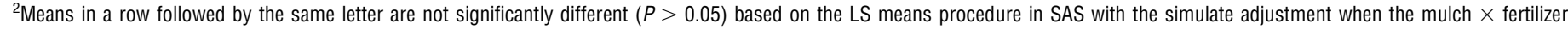
interaction was significant $(P \leq 0.05)$ (Table 1).

sandgrass canopy cover was greater with no fertilizer $(43 \pm 3 \%, n=48)$ than in fertilized treatments $(24 \pm 3 \%)$. Purple sandgrass canopy cover, averaged across fertilizer treatments, was greater (LS means, $P<0.05$ ) with geotextile fabric and giant reed transplants $(65 \pm 6 \%, n=12)$ than in other treatments $(\leq 40 \pm 5 \%)$.

Threeawn canopy cover in 1995, averaged across fertilizer and transplanting treatments, was greater in plots with commercial hay $(11 \pm 2 \%, n=48)$ than with native hay mulch $(4 \pm 1 \%)$ and was greater, averaged across mulch and transplanting treatments, in nonfertilized plots $(10 \pm 2 \%)$ than in fertilized plots $(5 \pm 1 \%)$ (Tables 4 and 5$)$. Averaged across mulch and fertilizer treatments, there was less (LS means,
$P<0.05)$ threeawn canopy cover in plots with vetiver transplants $(2 \pm 1 \%, n=24)$ than in plots with sandhill lovegrass $(10 \pm 2 \%)$, switchgrass $(9 \pm 2 \%)$, or giant reed $(8 \pm 2 \%)$ transplants. Sandbur was not recorded in plots with commercial hay, but sandbur canopy cover was $20 \pm 3 \%, n=48$, averaged across fertilizer and transplanting treatments, in plots with native hay mulch.

Hoary milkpea and camphorweed were the dominant plant species 10 years after planting, as in experiment 1 (Table 4). Canopy cover of plant species was similar among treatments in 2004, except: 1) threeawn canopy cover was greater in treatments with commercial hay $(5 \pm 1 \%, n=48)$, averaged across fertilizer and transplanting treatments, than in native hay 
Table 3. Means and standard errors (SE) $(n=6)$ for canopy cover of sandhill lovegrass, switchgrass, and vetiver during October 1994, 1995, and 2004. Treatments were applying native hay vs. geotextile fabric followed by commercial hay and fertilizer vs. no fertilizer during March and April 1994 to establish vegetation on sand dunes, Kenedy County, Texas.

\begin{tabular}{|c|c|c|c|c|c|c|}
\hline \multirow{3}{*}{$\begin{array}{l}\text { Year and } \\
\text { treatment }\end{array}$} & \multicolumn{6}{|c|}{ Plant species } \\
\hline & \multicolumn{2}{|c|}{ Sandhill lovegrass } & \multicolumn{2}{|c|}{ Switchgrass } & \multicolumn{2}{|c|}{ Vetiver } \\
\hline & Mean & SE & Mean & SE & Mean & SE \\
\hline \multicolumn{7}{|l|}{1994} \\
\hline \multicolumn{7}{|l|}{ Hay } \\
\hline Control & 1 & 1 & $7 b^{1}$ & 4 & $10 \mathrm{c}$ & 2 \\
\hline Fertilized & 19 & 2 & $13 b$ & 9 & $12 \mathrm{C}$ & 3 \\
\hline \multicolumn{7}{|l|}{ Synthetic } \\
\hline Control & 50 & 6 & $27 \mathrm{~b}$ & 3 & $33 b$ & 2 \\
\hline Fertilized & 88 & 8 & $94 a$ & 5 & $76 a$ & 7 \\
\hline$P$ & $0.085^{2}$ & & $<0.001$ & & $<0.001$ & \\
\hline \multicolumn{7}{|l|}{1995} \\
\hline \multicolumn{7}{|l|}{ Hay } \\
\hline Control & $2 b$ & 1 & $8 b$ & 4 & $33 b$ & 7 \\
\hline Fertilized & $3 b$ & 1 & $13 b$ & 6 & $25 b$ & 8 \\
\hline \multicolumn{7}{|l|}{ Synthetic } \\
\hline Control & $21 b$ & 5 & $9 \mathrm{~b}$ & 4 & $55 a b$ & 9 \\
\hline Fertilized & $49 a$ & 7 & $57 a$ & 12 & $75 a$ & 6 \\
\hline$P$ & 0.001 & & 0.011 & & 0.020 & \\
\hline \multicolumn{7}{|l|}{2004} \\
\hline \multicolumn{7}{|l|}{ Hay } \\
\hline Control & 0 & & 1 & & 2 & 1 \\
\hline Fertilized & 0 & & $\mathrm{~T}$ & & 2 & 1 \\
\hline \multicolumn{7}{|l|}{ Synthetic } \\
\hline Control & 0 & & 1 & & 5 & 3 \\
\hline Fertilized & 0 & & $\mathrm{~T}$ & & 3 & 1 \\
\hline$P$ & & & 0.942 & & 0.670 & \\
\hline
\end{tabular}

${ }^{1}$ Means for a plant species and year in a column followed by the same letter are not significantly different $(P>0.05)$ based on the LS means procedure in SAS with the simulate adjustment.

${ }^{2}$ Main effect of mulch treatment was significant $(P<0.001)$ main effect of fertilizer significant $(P<0.001)$ native hay $10 \pm 3 \%$, commercial hay $69 \pm 7 \%$; control $25 \pm 8 \%$, fertilized $53 \pm 11 \%$.

mulch $(1+1 \%)$; and 2$)$ averaged across fertilizer and transplanting treatments, sandbur canopy cover was greater in native hay mulch treatments $(8+1 \%)$ than in commercial hay $(2 \pm 1 \%)$ (Table 3$)$.

\section{DISCUSSION}

Results based on the first 2 years after planting might be interpreted to indicate that fertilization, seeding, and transplanting are needed to improve vegetation establishment on the migrating sand dunes in our study. Long-term results of the study indicate, however, that these treatments have little
Table 4. Dependent variables with $>2 \%$ canopy cover during October 1994, 1995, and 2004 having significant $\left({ }^{\star} 0.05-0.01,{ }^{* *} 0.01-0.001\right.$, and $\left.{ }^{* * *}>0.001\right) P$ values for main effects or interactions in analyses of variance. Independent variables in analyses were application of native hay vs. geotextile fabric followed by commercial hay (M), fertilizer vs. no fertilizer (F), and transplanting giant reed, sandhill lovegrass, switchgrass, and vetiver vs. no transplanting (T) during March and April 1994 to establish vegetation on sand dunes, Kenedy County, Texas. Numerator and denominator degrees of freedom for calculation of $F$ values were 1 and 15 for mulch, fertilizer, and the mulch $\times$ fertilizer interaction and 1 and 60 for other main effects and interactions.

\begin{tabular}{|c|c|c|c|c|c|c|c|}
\hline $\begin{array}{l}\text { Year and } \\
\text { variable }\end{array}$ & $\begin{array}{c}\text { Mulch } \\
(\mathrm{M})\end{array}$ & $\begin{array}{c}\text { Fertilizer } \\
(\mathrm{F})\end{array}$ & $\begin{array}{c}\mathrm{M} \times \\
\mathrm{F}\end{array}$ & $\begin{array}{c}\text { Transplanting } \\
\text { (T) }\end{array}$ & $\begin{array}{c}\mathrm{M} \times \\
\mathrm{T}\end{array}$ & $\begin{array}{c}\mathrm{F} \times \\
\mathrm{T}\end{array}$ & $\begin{array}{l}\mathrm{M} \times \\
\mathrm{T} \times \mathrm{F}\end{array}$ \\
\hline \multicolumn{8}{|l|}{1994} \\
\hline Litter & $\star * *$ & $* * *$ & * & $\star * *$ & $\star * *$ & & \\
\hline Partridge pea & $\star * *$ & $\star \star \star$ & $\star \star *$ & & & & \\
\hline Purple sandgrass & $\star * *$ & $\star \star \star$ & $\star \star \star *$ & & & & \\
\hline Sandbur & $\star *$ & * & * & & & & \\
\hline \multicolumn{8}{|l|}{1995} \\
\hline Bare ground & * & & & & & & \\
\hline Litter & $* *$ & * & * & * & & & \\
\hline Standing dead & ** & & * & & & & \\
\hline Purple sandgrass & $\star \star$ & $\star \star \star$ & & $\star \star \star$ & * & & \\
\hline Sandbur & $\star * *$ & & & & & & \\
\hline Threeawns & * & * & & ** & & & \\
\hline \multicolumn{8}{|l|}{2004} \\
\hline Sandbur & $\star \star$ & & & & & & \\
\hline Threeawns & $\star *$ & & & & & & \\
\hline
\end{tabular}

influence on canopy cover and composition of vegetation 10 years after they are applied.

Application of nitrogen is often considered essential to establish vegetation on nitrogen deficient sand dunes (Gadgil and Ede 1998). Possibly, periodic application of fertilizer during the entire 10 years of study would have maintained treatment differences. Annual fertilizer application on coastal barrier island dunes in Virginia resulted in differences in vegetation composition and diversity between fertilized and control plots during a 7 year period (Day et al. 2004). Fertilization, however, is apparently unnecessary to accomplish the goal of establishing vegetation on inland sand dunes in the Coastal Sand Plain of Texas because: 1) plant species canopy cover was similar in fertilized and unfertilized plots 10 years after planting, and 2) plant species that were favored by fertilization during 19941995 were replaced by other plant species by 2004 .

Seeding and transplanting likewise appear unnecessary for establishing vegetation on these inland sand dunes because native plant species colonized and established naturally. The abundance of camphorweed on the dunes in our study 10 years after treatments to stabilize the vegetation were implemented was not surprising because it is the dominant forb on ridges of stabilized dunes in the Texas Coastal Sand Plain (Diamond and Fulbright 1990). We did not document the seed composition of the native hay mulch or of the soil seed bank in the dunes before planting. Additional research is needed to determine the mechanisms of dissemination of seed of camphorweed, hoary milkpea, and other plant species on the dunes. 
Table 5. Means and standard errors (SE) $(n=24)$ averaged across seeding treatments for percent bare ground, litter, standing dead plant material, and canopy cover of plant species during October 1994, 1995, and 2004. Treatments were applying native hay vs. geotextile fabric followed by commercial hay, fertilizer vs. no fertilizer, and transplanting giant reed, sandhill lovegrass, switchgrass, and vetiver vs. no transplanting during March and April 1994 to establish vegetation on sand dunes, Kenedy County, Texas.

\begin{tabular}{|c|c|c|c|c|c|c|c|c|}
\hline \multirow[b]{3}{*}{ Category or plant name } & \multicolumn{4}{|c|}{ Native hay } & \multicolumn{4}{|c|}{ Geotextile fabric } \\
\hline & \multicolumn{2}{|c|}{ Control } & \multicolumn{2}{|c|}{ Fertilized } & \multicolumn{2}{|c|}{ Control } & \multicolumn{2}{|c|}{ Fertilized } \\
\hline & Mean & SE & Mean & SE & Mean & SE & Mean & SE \\
\hline \multicolumn{9}{|l|}{1994} \\
\hline Bare ground & 3 & 1 & $\mathrm{~T}$ & & $\mathrm{~T}$ & & $\mathrm{~T}$ & \\
\hline Litter & $20 b^{1}$ & 3 & $1 c$ & $<1$ & $60 \mathrm{a}$ & 4 & $17 \mathrm{bc}$ & 5 \\
\hline Partridge pea & $43 a$ & 4 & $13 b$ & 3 & $0 c$ & & $0 c$ & \\
\hline Purple sandgrass & $21 b$ & 3 & $78 a$ & 5 & $11 b$ & 3 & $24 b$ & 5 \\
\hline Sandbur & $2 b$ & 1 & $21 a$ & 3 & $0 b$ & & $0 b$ & \\
\hline Snakecotton & 26 & 6 & 50 & 5 & $\mathrm{~T}$ & & 0 & \\
\hline Other species & 6 & 2 & 8 & 2 & 3 & 1 & 14 & 4 \\
\hline \multicolumn{9}{|l|}{1995} \\
\hline Bare ground & 9 & 2 & 5 & 1 & 5 & 1 & 3 & 1 \\
\hline Litter & $14 b$ & 2 & $37 a$ & 5 & $10 \mathrm{~b}$ & 2 & $11 b$ & 2 \\
\hline Standing dead & $17 a$ & 2 & $7 b$ & 2 & $5 b c$ & 2 & Tc & \\
\hline Purple sandgrass & 38 & 3 & 17 & 3 & 48 & 5 & 31 & 5 \\
\hline Sandbur & 13 & 3 & 27 & 5 & 0 & & 0 & \\
\hline Sunflower & 4 & 2 & 0 & & 6 & 2 & 4 & 3 \\
\hline Threeawns & 6 & 1 & 3 & 1 & 14 & 3 & 7 & 2 \\
\hline Other species & 7 & 2 & 2 & 1 & 7 & 2 & 5 & 2 \\
\hline \multicolumn{9}{|l|}{2004} \\
\hline Bare ground & 14 & 2 & 17 & 3 & 18 & 3 & 16 & 3 \\
\hline Litter & 14 & 2 & 14 & 2 & 12 & 2 & 11 & 2 \\
\hline Standing dead & 8 & 1 & 8 & 1 & 11 & 1 & 8 & 1 \\
\hline Brownseed paspalum & 6 & 1 & 8 & 2 & $\mathrm{~T}$ & & 1 & 1 \\
\hline Camphorweed & 30 & 3 & 30 & 3 & 21 & 3 & 29 & 4 \\
\hline Coast indigo (Indigofera miniata Ort.) & 2 & 1 & 2 & $<1$ & 4 & 1 & 3 & 1 \\
\hline Hoary milkpea & 29 & 2 & 32 & 3 & 31 & 3 & 27 & 2 \\
\hline Sandbur & 9 & 2 & 7 & 1 & 3 & 1 & 2 & 1 \\
\hline Threeawns & 1 & 1 & 2 & 1 & 4 & 1 & 6 & 1 \\
\hline Other species & 7 & 2 & 2 & 1 & 7 & 2 & 5 & 2 \\
\hline
\end{tabular}

${ }^{1}$ Means in a row followed by the same letter are not significantly different $(P>0.05)$ based on the LS means procedure in SAS with the simulate adjustment when the mulch $\times$ fertilizer interaction was significant $(P \leq 0.05)$ (Table 4).

Partridge pea is an important plant for wildlife that is common on stabilized dune ridges in the Texas Coastal Sand Plain (Diamond and Fulbright 1990). Reasons for the initial abundance of partridge pea on unfertilized plots with native hay mulch in 1994 followed by its absence, or near absence, in these plots in 1995 and 2004 are unknown. The cover of partridge pea in 1994 probably resulted from germination of seeds present in the native hay rather than the seeds that were planted because there was only a trace amount of partridge pea in the geotextile fabric and coastal Bermuda hay treatment where seeds of the species were planted. Lower partridge pea canopy cover on fertilized plots possibly resulted because fertilization with nitrogen reduces nodulation (Alexander 1977) and because partridge pea was possibly less competitive with nonlegumes when nitrogen was added.

Mulching to inhibit movement of sand appears to be the most important factor in establishing vegetation on inland sand dunes. Reasons for greater threeawn canopy cover in geotextile fabric and commercial hay treatments in Experiment 2 than in the native hay mulch, and greater sandbur canopy cover in the native hay mulch are unknown. These differences appear to be of little importance relative to the overall goal of establishing a cover of vegetation on the dunes to stabilize them. We compared only 2 types of mulching material among several that possibly can be used (Armbrust 1977; Zak 1977). Additional research is needed to determine if other materials such as asphalt, crop residues, and manure are effective in stabilizing the dunes and are cost-effective.

\section{MANAGEMENT IMPLICATIONS}

Active sand dunes add to landscape mosaic diversity of the Coastal Sand Plain because they have plants and animals that 
are unique to them (Fulbright et al. 1990; Fulbright and Bryant 2002). It is not the intent of the authors to advocate stabilizing all dunes, but primarily those that threaten expensive improvements such as windmills, working pens, water lots, traps, roads, and buildings. Inferences based on this study apply to the specific location and conditions in the study, such as a decade of rainfall above the long-term average and protection from livestock grazing, and caution should be used in extrapolating results to other areas.

Mulching alone with adequate material to inhibit sand movement appears to be sufficient for vegetation to establish on migrating sand dunes in the Coastal Sand Plain that are protected from livestock grazing. Mulching alone is much less expensive than mulching, fertilization, seeding, or a combination of these treatments. For example, in our study mulching with native hay cost $\$ 19 / \mathrm{m}^{2}$ compared to $\$ 59 / \mathrm{m}^{2}$ for mulching with native hay, fertilization, and seeding combined. The lower cost of mulching alone outweighs the greater cost of obtaining short-term increases in canopy cover resulting from fertilization, seeding, or transplanting.

Fabrics are considered to be the equivalent of straw in their effectiveness as mulch (Kay 1987). The geotextile fabric we used deteriorated rapidly, possibly in part because of high wind velocities in the study area. Thus, synthetic geotextile materials alone are not recommended for stabilizing sand dunes in the Coastal Sand Plain.

\section{ACKNOWLEDGMENTS}

The authors thank J. Keepers, C. Wolter, T. McWhorter, M. Hehman, R. Palmer, J. Corliss, H. Freeman, S. Patton, and R. DeYoung for their valuable assistance in different phases of this project. G. McBryde estimated treatment costs. R. Bingham assisted with statistical analyses.

\section{LITERATURE CITED}

AleXander, M. 1977. Introduction to soil microbiology. 2nd ed. New York, NY: John Wiley and Sons. $467 \mathrm{p}$.

Armbrust, D. V. 1977. A review of mulches to control wind erosion. Transactions of the American Society of Agricultural Engineers 20:904-905.
Blake, C. T., W. W. Woodhouse, E. D. Seneca, and S. W. Broome. 1973. Vegetative dune stabilization in North Carolina. North Carolina Agricultural Extension Service Agronomy Information leaflet, Beach and Dune Stabilization Series No. 1, Raleigh, NC.

BonHam, C. D. 1989. Measurements for terrestrial vegetation. New York, NY: John Wiley and Sons. $338 \mathrm{p}$.

Brandle, J. R., L. Hodges, and X. H. Zhou. 2004. Windbreaks in North American agricultural systems. Agroforestry Systems 61:65-78.

Day, F. P., C. Conn, E. Crawford, and M. Stevenson. 2004. Long-term effects of nitrogen fertilization on plant community structure on a coastal barrier island dune chronosequence. Journal of Coastal Research 20:722-730.

Diamond, D. D., AND T. E. Fulbright. 1990. Contemporary plant communities of upland grasslands of the Coastal Sand Plain, Texas. Southwestern Naturalist 35:385-392.

Fulbright, T. E., and F. C. Bryant. 2002. The last great habitat. Special Publication Number 1. Kingsville, TX: Caesar Kleberg Wildlife Research Institute. $32 \mathrm{p}$.

Fulbright, T. E., D. D. Diamond, J. Rappole, and J. Norwine. 1990. The Coastal Sand plain of southern Texas. Rangelands 12:337-340.

GadGiL, R. L., And F. J. Ede. 1998. Application of scientific principles to sand dune stabilization in New Zealand: past progress and future needs. Land Degradation and Development 9:131-142.

KAY, B. L. 1987. Modifications of seedbeds with natural and artificial mulches. In: G. W. Frasier and R. A. Evans (EDS.). Proceedings of Symposium Seed and Seedbed Ecology of Rangeland Plants. 21-23 April, 1987. Washington, DC: U.S. Department of Agriculture, Agricultural Research Service. p 221-224.

Littell, R. C., G. A. Milliken, W. W. Stroup, and R. D. Wolfinger. 1996. SAS system for mixed models. Cary, NC: SAS Institute, Inc. 633 p.

National Research Council. 1993. Vetiver grass: a thin green line against erosion. Washington, DC: National Academy Press. $171 \mathrm{p}$.

Paschke, M. W., C. Deleo, and E. F. Redente. 2000. Revegetation of roadcut slopes in Mesa Verde National Park. Restoration Ecology 8:276-282.

Salmon, J., D. Henningsen, and T. McAlpin. 1982. Dune restoration and revegetation manual. Pensacola, FL: Florida Sea Grant College, University of West Florida. Report Number 48. $60 \mathrm{p}$.

SAS InStITUTE, Inc. 1989. SAS user's guide: Statistics. Vol. 1. Cary, NC: SAS Institute Inc. 943 p.

Whisenant, S. G. 1999. Repairing damaged wildlands: A process-oriented, landscape-scale approach. Cambridge, UK: Cambridge University Press. $312 \mathrm{p}$.

ZAK, J. M. 1977. Direct seeding of grass species for sand dune stabilization on the mid-Atlantic sea coast. International Journal of Biometeorology 21:238-244. 